An extract from an American paper to show that our neighbours are no better off than ourselves :-

Drrens.-The Port Royal correspondent of the Baltimore American gires an account of the operations of the dirers employed to clean the bottoms of the Honitors. Ife says that the principal direr-appropriately named Waters-is so used to this work, that he has become almost amphibious, remaining for fre or six hours at a time under water. The work is rery arduous. The direr sits upon a spar lashed athwart the bottom of the ressel, so arranged as to be mored as the work progresses, and with a scriper fixed to a long handle rrorks on both sides of himself as far as he can rcach. The mass of ojsters that become attached to the iron hulls of one of the Monitors, eren during one summer here, is immense. B5 actual measurement it was estimated that 250 bushels of oysters, shells, and sea-grass were taken from the bottom of the "Montauk" alone.

In the construction of composite ships with iron frames, I beliere, a great economy would bo found by shcathing on this plan; the destruction of the bolts, by the approximation of the copper, be avoided; and iron-fastened ressels coppered more effectually by the interposition of a waterproof medium. The application of copper, by adhesion, on the bottom of a wooden ressel, from the light line to the keel, would remore all possible risk of leakage, and injury to cargo from damp, the close adhesion would prevent oxidation internally, and the external waste be reduced, from the sheathing being dressed on a smoother surface.

In conclusion, I would ask what alternative has been proposed that promises to meet the difficulty excepting an application of copper sheathing. There is risk; but what is done without it. The powder in the magazine is merely isolated by a sheet of glass from the lightroom, but that risk is preferable to fumbling in the dark; and, to quote the words of Sir Joln IIay, when referring to this subject in the Ilouse, "I belicve if the talent and ingenuity of the country were appealed to, there is no doubt the practical difficulty could be overcome."

\title{
ANTI-CORROSIVE AND ANTI-FOULING COMPOSITIONS FOR IRON SIIIPS.
}

\author{
By F. N. Gisborse, Esq., C.E.
}

\section{Gentlemen,}

Before submitting the following brief observations relative to anticorrosive and anti-fouling compositions for use upon iron ships, allow me to acknowledge the valuable assistance rendered me in the preparation of this paper by my friend Mr. W. H. Walenn, a gentleman who has rendered great service to the public by condensing (to order of the Patent Law Commissioners) all the various patented inventions appertaining to electric science. Mr. Walem is himsclf the patentec of a very ingenious method for coating iron with copper, and from his know- 
ledge and experience was well qualified to aid me in rendering this paper instructire as well as interesting and reliable.

The introduction of iron in lieu of wood as a material for ship-building has raised several practical questions for the consideration of the shipwright, engineer, and man of science.

The stability of the structure, cxposed as it is to strains of peculiar character, the adjustment of the magnetic compass and other difficulties which have arisen have all been more or less successfully dealt with, and now we have one more desideratum pressing seriously upon the attention of all interested in naral architecture. I allude to the subject of the present paper, "Anti-corrosire and anti-fouling compositions for the bottoms of iron ships."

$\Lambda$ similar question formerly arose in regard to wooden ships, but the experience of years has been so well directed to the preservation of all ligneous structures when immersed in sea-water, that but little onxiety is now felt respecting their durability. That this was a matter which deserved and reccired much attention from our ancestors is abundantly manifested by the early date of patents having such an object in view, for we find that although letters patent were first granted lyy James I., 1617 , and then most sparingly granted, the thirty-sccond patent was secured to William Beale, in August, 1625, for " Preserving ships from hurt by the sea-worme or barnacle by means of certain cement or dressing."

The introduction of iron as a material for ship-building is of comparatively recent date. It appears, howerer; that a canal boat of iron was built 1787, and that iron canal boats were in general use 50 years ago. The IIorsley Iron Company, of Tipton, Staffordshire, built the first iron sea-going steamer, the "Aaron Mrauby," in 1821. Mr. Grantham navigated an.iron steamer on the Shannon, in 1824 , and from about 1838 to $18 \pm 0$, iron vessels began to come into general use. The appre: hension excited in the minds of shipwrights and shipowners respecting. the want of durability of iron in sea-going ressels, together with the henvy item of current expenditure for keeping iron vessels in serviceable repair, are so great that even now, many assert that rood-built ships maintain their superiority. Only last week, when I had the honour of reading a paper at Glasgow before the "Scottish Shipbuilders' Association," upon Electric Signals, there were many adrocates for composite ship-building, i.e., iron frames, planked and coppered, the great objection raised to all iron being the great cost of cleaning in forcign ports, and the great falling off in speed from the rapid growth of animal and vegetable matter, eren upon the best anti-fouling compositions known.

The corrosion of the iron wherever the sea air and sen water can act conjointly upon it is quite a secondary consideration, as compared with the annoyance and loss occasioned by the rapid fonling of iron ships, more especially when at anchor in tropical climates; and it is this chief difficulty which has engaged the attention of so many aspirants to fame and fortune.

As a matter of history, it may be mentioned that the ingredients of the paints usod for the preservation of wooden ships in ail the earlier

rot. $1 x$. 
patents were principally pitch, tar, resin, and sulphur, while the idea of poisoning the "sen-wormes" appenrs to have entered the minds of inventors about the year 1737. Metallic sheathing, howerer, either with or without a layer of felt between it and the rood, was at last the plan generally adopted.

The inventions that relate to the protection of iron ships from corrosion and fouling are extremely varied in the means cmployed to effect such purpose. In the early part of this century, Sir Humphrey Dary proposed, as a preventative against oxidation, the attachment of sheets of zine to all iron exposed to sea water relying upon the galranic action of the zine and iron. The result, however, of this arrangement proved that the iron was only in part prevented from rust, while its surface became eren more attractive for the growth of seawced and crustacen.

Some inventors rely entirely upon pitch and tar, and their mixtures with oleaginous and other organic substances.

Paints, properly so called, are employed by others cither with or without a previous preparatory coating.

Many experienced shipwrights are of opinion that nothing surpassed ordinary red lead, or white zine, mixed with boiled linsced oil; but these paints do not entirely prevent rust, while they permit the growth of weed and barnacles, and require very frequent renewal, and consequent dock expenses. To stop short, therefore, in the enquiry for an anti-corrosive and anti-fouling paint at this early stage of our experience, would bo to announco our belief in the impossibility of a perfect solution of the question, and would be utterly unworthy of the nation which is destined to be the grentest iron ship-bvilder in the world.

Other inrentors again apply cements, vitreous compositions, and eren vitrified surfaces to the ressel; Jeffrey's marine glue, or other glue in one instance being the means of attachment of vitrified iron plates. The application of Sir Humphrey Dary's metallic zinc plates is again revived, either as a total or partial covering, or with varieties in detail, and to this basis a large class of inventors hare turned their attention; others again interpose a layer of wood between the iron and the zinc plates with their fastenings, while others use felt in lien of wood for the same purpose. Amalgamated zine plates are another variety of the same general principle, while several inventors propose to encase cach iron plate within a thick coating of other metals.

Mr. W. II. Walenu has been particularly successful in encasing iron with copper or brass by galranic action, the latter metals being precipitated upon the iron to any thickness required.

To less than 57 patents, exclusively for paints for iron ships, are now in print, since the first protection was obtained in the year 1831, for an auti-corrosive and anti-fouling pigment for the bottoms of iron ships.

In some of these the composition consists of a mixture of salts of the metals with sulphur, or other readily-melted substance, and is applied hot. Gutta-percha, india-rubber, and other gum compositions lave their enthusiastic supporters. Pitch and its combinations with organic bodies appears from its cheapness and ready application to 
satisfy a large. number of inrentors. The farourite idea, luwrever, appears to be a revival of the old shipwright's notion of poisoning the "sen-wormes," accordingly, arsenic, antimony, sugar-of-lead, rerdigris, croton oil, cyanide of potassium, mercurial ointment, asafoctida, and strychnine figure in the list of material weapons brought to bear against the unconscious barnacles, and their tendency to growth (under difficulties) in contact with submerged iron. Essential oils, powdered glass, porrdered metals, plumbago, and other forms of carbon, metallic oxides, and gums, enter into the composition of the paints put forth by a great proportion of aspirants to fame in this department of practical science. One patentee adrocates the use of guano; two incentions relate to the use of oil, constantly expressed from pores in the sides of the ressel, so as to ooze out over the submerged iron plates. In one of these the oil is combined with arsenic. Clay, lime, and other mineral earths are announced by some inventors to form, in combination with other ingredients, a specific for the cvils complained of.

Among all these numerous patents there are, howerer, some few in general use which are of sufficient importance to merit particular notice.

Mr. William Joln IIay, $\Lambda$ dmiralty Chemist at the Doclsyard, Ports. mouth, has obtained two patents. The first, under date February 1st, 1858 , consists of a mixture of Trinidad pitch or asphaltum, vegetable tar, and naphtha, to which caontchouc, creosote, and turpentine may be added. The second patent, under date November, 1861 , is based upon the use of protoxide of copper, ground and boiled in linseed oil, until reduced to suboxide, to which silver or its oxide may be added, with naphtha or turpentine as a drier.

It is wisely recommended that a protective conting be applied to the iron before this anti-fonling composition is used.

Green's and Pencock and Buchan's paints are also among the fer best known to commerce. I am not aware of the basis of these paints, but am informed that arsenic and carbonate of copper are respectively combined with them.

Jeffery's marine glue has been used alone, and in connection with other inventions. The patent has expired some jears; the composition is based upon caoutchouc and shellac.

MIcInnes has also two patents, the first under date June, 185. This composition consists of pale yellow soap and sulphate of copper.

That of the 2nd of October, 1856, relates to a composition containing powdered emery and shellac, dissolved in spirits of wine and mixed with resin, castor oil, and ammonia, to which ground glass, sand, and cement may be added.

Dr. White patented, in 1863, a pigment composed of tallow, oil, and powdered quicklime.

The object of the foregoing and most generally known inrentions, is evidently based upon two principles, viz, either to poison crustacere and marine vegetation, or to offer a continually changing surface of so unstable a nature, that neither shell fish nor weed can take permanent hold of their first resting place. 
This latter intention I beliere to be the first step towards a solution of the question. All of the foregoing inventions are now before the public, and have met with more or less success in various climates, and under varied circumstances, for it is a curious fact that the results obtained from arowedly the same composition, will prore either a " success" or a "failure," under apparently preciscly similar application, and when cxposed to the same run of ocean.

It is therefore with the utmost deference to the ingenuity and experience of other inventors, that I now state the component parts of my own composition, and endeavour to offer a reasonable explanation of the grounds upon which I rely for success.

My patent is dated October, 1863 , and was secured only after a twelremonth's private trial of its capabilitics. It consists of a combination of quicksilver, rermilion, oxides of lead, powdered flint, glass, litharge, and boiled linseed oil, in such proportions and so triturated and ground together, that the large proportion of quicksilver used, namely, one-fourth, and in some instances one-third of the entire weight of materials, disappears, and still more curiously remains in suspension throughout the entire mass months after mixing.

The theory, and I may now add the proved results of the foregoing combination is as follow's :-

First. That the paint is of such consistency ard "body", that it interposes a sufficient thickness of material between the sea water and iron surface, as will stand ordinary wear and tear, and at the same time is in some degree a waterproofing composition.

Secondly. That the attacliment of the paint, owing to its nature, is perfect when applied to a clean and dry surface of iron.

Thirdly. That the clemical action of the paint is not necessarily poisonous.

Fourtlily. That the charncter of the pigment enables it to evolve an element which is obnoxious to animal and detrimental to regetable existence, and that in so remarkable a manner that not only is the iron partially free from barnacles and other crustacen, but that not one attaches itself to iron thus protected.

Fifthly. That the paint itsclf slowly wears away, thus continually preventing an unstable surface for anything inclined to fasten upon it, and also at the same time exposing fresh chemical agencies to produce the effect hercinafter explained.

Lastly. That in case of any slight scratch or abrasion in the coating, the exposed iron is, to a considerable extent, protected by the adjacent composition.

In all ages, and for various purposes, quicksilver forms illustrations of a remarkable character. Some philosophers believe that the Egyptian magicians employed it when Moses defied them before Pharual to cast down their rods, and to cause them to become serpents. Dodalus is reported to have moved a wooden statuc of Venus by means of a stream of inercury, while at the present day mercury is employed to show the hent and weight of the atmosphere, and to cure diseases. The advance of physical, electrical, and chemical science is greatly due to its adaptability to various purposes. The 
mercurial trough for the collection of gases that are soluble in water, the use of mercury as a reflecting medium in optics, its conductability of heat and electricity, its fluidity at ordinary temperatures, its high specific gravity, its power to dissolre metals, and its easy volatility, present a combination of properties that is rarely met with in an isolated elementary body. One other property of quicksilver which cnables it to be cmployed as a metallic paint is its singular affinity for oleaginous substances, and it may be stated here that it has strong sympathetic and anti-pathetic tendencies, which are not only manifested by chemical affinities, but by aflinities not less strong (although their display is more rare), of which physical science takes especial cognizance. The power of mercury to unite or amalgamate with metals in general, and the repellant action of mercury on iron and platinum are illustrations respectively of these sympathetic and antipathetic tendencies.

The forces by which the particles of bodies are held together, are-

Firstly. "Cohesion;" by means of which particles of an identical character form a mass.

Secondly. "Adhesion;" by means of which particles of difierent linds form a mass, each constituent particle retaining its individual propertics.

Thirdly. "Chemical affinity;" in which particles of different kinds. unite to form a mass, the properties of the resulting compound being of a totally distinct character from those of its constituent particles.

It is to the sccond development of force, "adhesion," that the attraction or affinity of mercury for oleaginous substances belongs. This adhesive force is much increased by the increase of surface of the bodies brought within its infuence. There is every reason, in fact, to beliere, that adliesion increases in direct proportion to the increase of surface. By pulverizing a substance, the surface is increased to its maximum in proportion to the weight of the substance. Dr. Miller calculates that if a cube of one inch in the side is subdivided into a number of cubes, each of which is $\frac{1}{000}$ th of an inch in the side, the adhesire force is increased 1,000 times. The size of the globules of the paint now under consideration is so minute that they are undistinguishable by the naked eye, the quantity of light which they collectirely reflect being so small as not to interfere perceptibly with the colour imparted to the paint by its other constituents, although, as before stated, there is 30 per cent. of metallic mercury in it. The average diameter of the globules is ascertained to be $\frac{1}{10000}$ th of an inch, and the adhesire forec is increased by communition in comparison with that of a sphere or globule one inch diameter, 10,000 times. The natural adhesive power of mercury for oil, and the minute degree of fineness to which it is reduced in this paint, accomts for the singulnr fact that whilst the powdered flint glass employed to divide the globules in the first instance, when manufacturing the paint, is partially deposited at the bottom of the containing vessel if the paint be at rest for some time, yet the mercury is retained in suspension with little or no tendency to scparate itself from the other ingredients of the composition, thus nentralizing the powerful effect of the attraction 
of "graritation" upon mercury by the still more powerful effect of the attraction of "adhesion" of the mercury for the boiled linseed oil in the paint.

Other means besides attrition with oil are known of comminutings mercury and bringing out its adhesive force for certain other substances. Some substances cause the derclopment of the force to a greater degree than others. When pure mercury is shaken with water, cther, or oil of turpentine, or rubbed with sulphur, sugnr, chalk, lard, conserve of roses, \&c., \&c., it is rers highly comminuted. If metallic mercury is precipitated by adding an aqueous solution of proto-chloride of tin to an aqueous solution of bi-chloride of merenry (corrosive sublimate), the precipitate takes sereral hours to subsi!le; and if running mercury is agitated in dilnte sulphuric acid in contact with a few crystals of sulphate of copper, electrolytic actions cause hydrogen gas to be given off at the surface of the mercury, while the mercury assumes the form of froth.

The uses of comminuted mercury hare, until lately, been almost entirely confined to its therapeutic action upon the human system. The mercurial ointment, bluepill, and "pulvis hydrarg cum cretî" of the pharmacopocias are instances of its application as a curative agent. In contradistinction to this, it may be noticed that Brande in his "Chemistry" states that it is probable that mercury, administered to the lhuman system in mass, is medicinally inactire. An inrentor finds another use for the compound of mercury with grease, by employing it to insulate those parts of the zine plates of galvanic batteries that are not directly opposed to the negative plates.

$\Lambda$ s the mercury exists in my paint, there can be no effect produced upon the marine regetable and animal deposits, such as bannacles, by the agency of any poiscnous substance, but other experimenters and patentees hare sought to obtain the desired results by poisoning marine animals and plants, such being an impossibility. Professor Wilson tried many careful experiments in proof of such assertion. IIo mixed the most subtlo poisons knomn with ordinary ship's paint, and after barnacles of large size had gromn upon the wood and iron thus protected, he boiled the fish, and with such food poisoned many animals within a brief period, thus proving that mollusks could imbibe the poisonous matter into their systems without detriment to their own existence. The Chairman of the Scottish Slipbuilders' Association also stated the other erening that an iron plato had been coated in squares with four of the best known anti-fouling compositions, and after some months' submergence was raised for examination. The plate was covered with barnacles, and, ludicrous to relate, the biggest fellow among them had fastened in the very centro of the plate corering the junctions of the four paints, as if to taste and defy the rillainous bait laid for himself and compeers.

With such testimony before us, I think we may very fairly conclude that henceforth we must look to other agency than poisoning as the basis for anti-fouling compositions. In my paint I have endearoured to obtain the desired result by the combination of two theories, one being the gradual wearing array of the paint from its surface by the action and attrition of moving sea-water, and the other from electric action 
upon the delicate organisation of incipient life in either animal or regetable matter, always bearing well in mind that such chemicals are made use of, as shall in no possible manner gire rise to galvanic action at the expense and to the consequent detriment of the very material we seck to protect. It is upon the latter reasoning thint objection arises to all paints containing copper, which is in itself an clement of destruction to the iron plates of a ressel aflont; this arises from the tendency of the salt, or precipitate of copper, which gires body to the paint, to become decomposed and to yicld up its copper in the metallic state, and in contact with the iron. These obscrrations apply to any paints in which metallic substances clectronegative to iron in sea-water are made use of.

It is only after numerous experiments, in which I hare been materially aided by my coadjutor, Mr. John Hughes, in many of our part works, and during which we hare had to devinte from the specification of my patent, that successful results hare been obtained; and it is a curious fact that even with the same weight of mercury cmployed, slight additions or subtractions from our present formula most materially affect the lasting value and effects of the composition.

Twenty jears ngo, when in the Gulf of Mexico, the Captain of the ressel I was in tried experiments with mercurial ointment taken from his medicino chest, with little or no effect upon crustacea. The idea then was to poison or salirate the shell fish, and, lately, Captain R. Johnson has taken out, but since abandoned, a patent in which he tried the effect of one-eighth part of mercurial ointment and one-eighth part powdered arsenic in his composition.

Before an inventor in this country can' obtain aid to introduce a new material he finds it necessary, in the first instance, to obtain a "patent" or "protection" (the latter frequently proving an expensire misnomer). This, as you are atrare, I have done, and I have hirl before sou the main features of the composition therefrom; but the secret of manufacture, \&c., which is only of personal interest, I feel sure you will readily excuse my entering upon.

From trials, which have extended orcr twelre months cach, it appears that plates and ressels coated with this paint are as free from animal or regetable growths when taken out of the sen-mater as when placed therein, while the material has worn away but maintained its rirtucs to the last film. All testimonies tend to show that not only is freedom from barnacles secured (eren though the conted surfaces are stationary in sea-rrater at places most forourable to their growth), but that the grass overhanging the upper edges of the scetions on ships allotted for experiment is dwarfed in growth and of lighter colour than that which is contiguous to my composition.

There is clearly, therefore, some other actire agent at work, which I thus explain: Electric or galvanic action can be excited between two fluids of different nature, and one metal as between two different metals and one fluid.

The quicksilrer is the metal which I employ, the salt water one fluid, and the acids peculiar to crustacea and marine regetation the other fluid.

You thus create, under the fish or vegetable germ, as many galvanic 
batteries acting upon their extremely delicate organization, as there are minute points or globules of mercury in contact with them. There is also a certain anount of resilience or clasticity in my paint which I attribute to the film of oil between the mercury and iron remaining. moist, and thus in itsolf protecting the iron to a certain extent; this is also a valuable adjunct in assisting the mercury to flow over and protect the iron in case of any slight scratch or abrasion, and forms one of the peculiar properties of the paint., The attachment of the mercury to the naturally repellant iron by aid of the oil is thus a good example of the adhesive force already explained.

Such, Gentlemen, is the theory of my composition, and, in conclusion, I will call your attention to one or two certificates which yon can substantiate to your orrn satisfaction, bearing in mind that from the raried alterations in the course of our manufacture we have made errors, since discorered and corrected, which would have been more or less discouraging had we not proved that the basis of the invention was unquestionably correct.

The officers of the steamer "Caroline," running in the Mediterranean, pronounced my sections after twelve montlss trial, during which time the rest of the vessel was three times painted with other paints; as clean as when first coated with the composition. This steamer is now owned by MIr. IIenley (the well-known clectrician) who will confirm their statement. I beliere she is at anchor in the Thames at the present time.

Captain Jackson, Lloyd's agent at Milford Haren, thus writes of the plate now before you. "' "his plate was submerged in Milford Maven waters for orer sixmonths, and at the termination of that period was found to be worthless on the red lead side; but perfectly free from corrosion, weed, and barnacles on your composition side," a similar result was reported of a plate ten months submerged, and he adds, "You may depend upon the practical ralue of this composition, and you may refer shipowners to my experience in almost ercry patent composition extant. I have seen none that will compare to the one now referred to." Similar evidence has arrired from Mnlta, while lately our experimental vessels have been arriving from all parts of the world, and the owners are purchasing the composition largely.

Among other successful experiments I may mention the "Eastern Prorince," of the Diamond Stcamship Company, although the paint uscd upon that ressel and one other betonging to the company was among our experimental crrors, by which the addition of peroxide of iron reduced its lasting though not its effective qualities fully one-half. The "MIcGregor Laird," of the African Steamship Company, also painted with the peroxide of iron mixture, came in clean, and tho "Aleppo," lielonging to the Cunard MIediterranean flect, was last week docked and found clenn.

I lare now the pleasure to add that, after some successful experiments in the Medray, wo have executed an order from the Lords of the Admiralty to paint IIer Majesty's ship "Valimut." This ressel we have coated upon ono side only, Mr. IIay (Admiralty Chemist) and another patentee having the other side for competitive trial. 
We are still experimenting; with a view to making our paint last orer a longer period than twelve months withont detriment to the qualities which it now possesses.

In conclusion I may add, that although necessarily costly from the expensire nature of its component parts, i.e., costly per cwt., yet it spreads over so large a surface that it is not beyond the pale of commercial sale, while, shonld continued trial prove it to be all that we believe it to be, the extra speed, and inmense saving of time, and dochage expenses will make it a boon to all iron-ship owners, and a valuable adjunct to our naral superiority.

MIr. J. W. IIs, II.MY. Dockyard, Portsmouth: I am a stranger who has been inrited here, and I may, perhaps, be allowed to clear up a point wlich has been mooted by my friend, Captain Warren. In the Transactions of the Institution of Thatal Arehitects an error of the reporter las occurred, which I nerer sars until the Transactions were in my hand. For any scientific purpose, or for the gentlemen who are in this room, $I$ do not consider it necessary to explain that error ; but I wish to clear array any imputation that might be put upon my professional character. Then the meeting was on the point of breaking up, and the roon was consequently in a state of disturbance, the question was asked, "MIr. Hay, what effect would thee feet, fire fect, or one foot of wood lare in stopping galranic action betrecn MIuntz's metal and armour plating $f$ " Fnorring, as I did, that XIuntz's metnl had been placed on ships, and that the only man who cught to hare been consulted had not been consulted, and this mas a professional officer that asked the question, $I$ stated that before they sheathed an iron-ship or an armour-cased ship, they should hare consulted the man who had been deroting his encrgies from twenty to twenty-fire Jcars to the serrice, in a clemical point of rier. That was my remark; but in the confusion occasioned just as the mecting was breaking up, it was misunderstood, and I pardon the reporter. I did not consicler it necessary to erplain the crror; indeed, I never thought any gentleman would chaff me with the ridiculous imputation that we must mait twenty or twenty-fire years before sheathing an iron ship, when we do not know from hour to hour that we may not require the ships in action. I beg simply to explain this, because I do not wish gentlemen to go away with the notion that I could hare made such an assertion. I am sorry that Captain Warren should hare alluded to the newspaper reports respecting one or tro ships. The "Resistance,"-unfortunately, we only get part of the information,-liappened to be coated simply with a protective rarnish. She Teut out to Mrnita, and at Malta she was "logged" without disturbing the composition in any way that had been put on cight months before. But being in dock, it was considered necessary, owing to where the chain cable had rubbed and other places, to coat this ship's bottom. But as there was nothing at Malta suitable for the purpose but the protectire ramish, the protectire raruish was alone put on. The protectire rarnish consists simply of asplalte, piteb, and naphtha, which we nerer for one moment consider will prerent ansthing like fouling. This ship was docked again in six montlys. She nerer had Iray's composition put on her. And as to the report about the "Recruit," it is bencath me to notice it. I regret that it should hare been neccssary to make these remarks; and thank you for the patience with which you hare listened to me.

Captain Craigle IIsketr : Is I am one of many indiriduals nbo hare taken an interest in the discorery of a coating for the prevention of fouling in iron ships, I should like to say a few mords in connection with the subject under discussion. I do not propose to take up the question of sheathing brought formard by Captain Warren; nor shall I attempt to remark at all on nuavy of the coatings which at rarious times hare becu suggested; but I shall limit myeelf to the consideration of certain points in reforence to the inrention of Mr. Gisbone, comparing his inrention with one presenting many analogies to it, in which I hare taken no small amount of interest. During the period in which $\mathbf{M}$ r. Gisborme was carrying on his experiments 
for the purpose of proving his inrention, there rere experiments going on in the neighbourlood of Edinburgh, which I had a good deal to do with. Those experiments were quite independent of his, and were carried on in perfect iguorance of his proceedings. They rere conducted in a sfstematic manner, and shored, after tho trials of a number of substances, that certain compound 3 of mercury were best able to ansmer the purpose of prerenting both fouling and oxidation. IIy reason for wishing to say a few words here to-night, is because the patent that $I$ am about to allude to, is rers nearly connected with Mr. Gisborne's, and is, to a ccrtain extent, an opponent of his. With reference to the oxidation of iron, re all know that mercurial ointment has been used many jears for the prevention of corrosion. Erery Ensign who goes out on foreign service, finds a jar of mercurial ointment in his gun case, put there by his gun-maker, to be rubbed with a rag orer his gun or rifle on any occasion when the weapon is to be exposed to damp, especially to sea air or salt water. The results of the experiments before alluded to, formed the basis of a patent taken out by Mr. Fraucis Cruicksinnk, of Edinburgh. I will name the threc compounds of mercury which he employs; but before doing so, I would briefly state certain principles which were deduced from the experiments, as they hare a most inportant bearing upon the question at issuc. Firstly, I would state that a coating, in order to protect a ressel effectually from fouling, must contain some substance or substances which shall excito deleterious action on animal and regetable organisms. Secondly, that the chosen substance shall be insoluble, or so slightly coluble that, while acting energetically on the liring organism, the action of Eea water in contact with it shall be Tery slow. Thirdl, that the deleterious substance or substances shall be fixed to the ressel by means of a medium of sufficient hardness and toughness to resist the friction which a ressel necessarily encounters in passing through the water. In support of these principles, I may state that the experiments I hare been watching near Edinburgh, hare clearly shown that the animal and regefable organisms giring rise to fouling, are remarkably affected by contact with surfaces conted with rarious metallic poisons. In the case of the large majority of these, the absence of insolubility renclers them altogether uscless. The substances which are in the composition of Mr. Cruickshank's coating, in a wonderful degree possess the qualities upon mhich I have insisted. Thes are encrgetic poisons, not apt to rary in their composition, and when applied by means of a suitable conting or paint to iron plates, they have been found to protect them from fouling in the most effectual manner, whether the said fouling be caused by animal or regetable life. I will now mention the three compounds of mereury in $\mathbf{M r}$. Cruiclshank's patent:-First, Thite precipitate of mereury; second, oxichloride of mercurs-a term which includes rarious definite chemical compounds of corrosire sublimate and protoxide of mercury; third, the red oxide of mercury. I may add, that the powers which these ingredients possess to prerent fouling, will, I feel confident, prove raluable to the Admiralty and to the mercantile marine. Now, allow mo to say a word upon tho principles upon which MIr. Gisborne's invention is said to rest. I am far from saying that I think Mr. Gisborme's coating is not a successful one. I beliere it is a successful one. It has been alleged that the action of Mr. Gisborne's invention is purely mechanical, by means of electric action; and that this action is noxious to animal and regetable life. Whaterer action MIr. Gisborne's coating docs possess, I am satisfied that it is explained by the principlo I adrocate. I am firmly conrinced that the reason why it is so far successful, is because the mixing of his purc mereury with a greasy matter brings about a certain amount of oxidation in his metallic mercury, and it is that oxidation of his metallic mereury that is deleterious to animal and regetable life. MIr. Gisbome states that the electric action is affected by two luids and one metal. IIe states that the acids of the juices of the animal and regetable life are necessary to produco this electric action. We may naturally presume their adhesion and presence aro necessary; but $3 I$. Gisborme hecp theso organisms entirely off by his coating. The simultaneous presence and absence arc not easy to comprehend. Mretallic mercury possesses no poisonous action. Then combined with other elements, homercr, it gires rise to compounds possessing the most poisonous properties. Then mixed up ultimately with greasy matters, for instance, a rery small quantity of mercury is oxidised; and by this oxidation, the 
physiological action of the metal becomes altered, because a substance has been procured which is poisonous, and almost, if not entirely, insoluble in water:- a substance, therefore, posscssing properties which fit it for the protcetion of ressels from fouling. I am arrare that it will be objected that such powerful poisons as arsenic and tobacco, exert no action upon the animals which are, to a grcat extent, the cause of fouling. I mect this by saying, that becauso some poisons do not act injuriously upon marine animals, it is most illogical to argue that none can affect them. Innumerable instances occur of indiridual animals and plants becoming affected by eomo poisons and not by others; and it is an incontestable fact, that the substances which I hare named, not only protect iron from fouling, but actually are poisonons to marine animals. You will, therefore, admit that a coating which contains a definite amonnt of such insoluble and poisonous substances must be preferable to one whose action depends on the tardy and incomplete oxidation of metallic mercurs-an oxidation which will rary with the mode of the preparation of the mixture, and with the temperature, \&c. These were the reasons which induced me to join Mr. Cruickshank. I hare already receired the greatest justice from the Admirnitr, who hare been so lind as to gire me permission to coat a portion of one of their ships.

Mr. Beste: Does Captain Warren take any measure for rireting the surface, or does he put the glue on the surface of the metal? I understood from MIr. Gisborue that his composition will last for twelve months. I do not know how long Captain Warren says his patent will stand, how long the copper will remain firmly attached to the iron, and in how mans Jears it will be affected. Captain Warren spoke of the length of the commissions, but he did not state any definite period.

Rear-ddmiral Sir Edwano BeICHER, C.B. : For a great number of years ny attention has been directed to the fouling of copper on ressels by crustacen. I found, particularly at Bermuda, where we were stationed for two ycars, that the animaleule preferred the oxide of copper, which is poisonous, to any other substance on which they would fasten. I grew corals on my omn account. I began with Lady Lumley's scent bottle, and I grew a coral tree on it for her. I tried jars, bottles, iron, the back of a knife, the solo of a shoe, a slate, and erery possible substance that I could get hold of, and I had a beatiful museum of these things. The controller mrote to me the other day, asking my opinion whether coralline rould attach themselres to glass in preference to any other substance, and whether the coralline so attached would be more difficult to remore. I remarked distinctly, the corallines rere more diffeult to be remored from ritreous surfaces, and could not be remored by an ordinary scraper; but whererer they came into contact with copper, which is elightly oxidised, they scaled off immediately, becouse they came off with the oxidised portion. In 1824 Sir IInmpbrey Dary commenced his experiments, by adding zinc plates on either side of the stem, to endearour, by galranic action, to orereome oxidation. I do not know if chemists understand exactly why the animalcula decline to attach themselres to copper which is so protected; but if they will place a zine plate under the tongue, and a silrer plate orer the tongue, and bring the two in contact, they would find that the insect rould experience a tingling, sharp sensation, which would warn him off the copper. As loug as the protection was in proper proportion, and the galranic action kept up on the surface of the copper, to the destruction of the more oxidizable metal, zine, so long we had no insects settling on the outside of the copper. The zine was corered with weeds and coralline, but the copper, so far as I vituessed the experiment, was perfectly free from anything of the sort. In 182. we were trented in a different manner. TVe had under each fore-chain an iron plate, nine feet lopg, and abore four incles wide; and a similar one under the mizen-chain on each side. The ship was four jears and a-half in commission. Her copper was constantly bright and clean; but when we came home to England, weeds and animalcule were found ottached to those four spots. Thien the "Blossom" was docked she was perfectly vilear, except where the iron was; but the iron was gone, for as we were going into dock the iron tumbled of in a lump, in a state of oxide. In 1830 Captain Swceney took ont a patent with some Frenchman for protecting ships' bottoms sheathed with polished iron. II had a brig, and she was protected by this method, by zinc bars. Tanks were also fitted up at Portsmouth, aud water was kept in the polished tanks 
for four or fire years without any alteration taking place in these tanks. The brig which went out to IIalifas was found rery foul; the plan did not anster at all; but it did answer intermally in the tank.

The Chamanx: Were those tanks made of iron or zine?

Sir EDTrino BeIcner : Iron, witl zinc bars. At the time I fitted out, in 1831, the Goremment prorided me with zine bars for the purpose of folloming up thesc experiments. I found, where the connection took. place between the iron and copper, at the stem of the boat, that the zinc interposed there did protect the iron from corrosion. To sliow how rapidly barnacles will form, $I$ will mention an instance that came under my own experience. In 1830, when my slip was in dock, I had an idea that if I whitewashed it I should beep of a great part of the galranic action betricen the heads of the mails and the copper; and I thought that when the ship got to sea she would wash off all the rirer esum and be clean. Wo sailed in December, and we returned in the dugust of next year, only seren months amas. At the Nars Offe, in the collection made by Sir Trilliam Symonds, you will find barnacles four and a-half inches long taken off the ressel, and which were nomed after ne. They rere found in plates along the whole line of the keel, where the lead came in conjunction with the copper. That eircumstance shows how rapidly barnacles mill form on copper. I am afraid this composition of Captain Tarren will not staud the wear and tear, unless it is rery heary copper. Is that 32-ounce copper?

Captain Warnex: The 28.

Sir EnTARD BELCIER: When it comes in contact with a rock, or with any other rubbing substance, I question whether the difficulty will not be greater than if the end were not simply pointed. I beliere a patent will be taken out at the end of this week for the protection of the walls of the Houses of Parliament. The inrentor of the sceret has a peculiar ramish, which has been applied to iron that has been for four scars under water; it may be seen at the Kensington MIuseum. The rarnish which mas under water the whole time was less affected than the ramish which was exposed abore water. It was applied under Sir. Baldirin Walker's directions, and was forgotten for a time.

The Cinsmuax : Do jou know the price of that rarnish?

Sir EDward BeLcher: It will be rery cheap indeed; but until it is patented no one will know any thing about it. But I can tell fou what the ground work of it is. Fero ras buried in his ressel, which was corered with this same pigment. It has no moisture in it at all; and it will not yield moisture under distillation at red heat. Tho rarnish in question has puzzled Professor Faraday. IIe states that, so far as lo knows, it will do erergthing that the patentec states it will do. When Ficro's ressel was got out, a portion of it was placed in the JIuscum at Pome; and Cardinal Mezzofanti allowed this man to buy some portion, and with that ho bought his sceret, for he examined the paint and discorered what it was made of. I hare scen two letters, one from. Glasgow and another from Iirerpool, asking for further supplics of the paint, stating also "it is the best corering for bottoms thes hare had as jet."

Mr. IEETCII : I haro heard with a great deal of pleisure the arguments this cren. ing. I think the subject is one of sufficient importance to call for a few obserrations. The first thing is to preserre iron from corrosion; the next thing is to prevent the adhcsion of the animalcula to it. All the attempts to nse copper on iron vessels hare hitherto been failures, because the galranic action which will result from damage to a portion of the copper, will cause the galranie current to go right througis. It at first sight scems a ridiculous idea to think of glass, because, being so brittle, it is beliered that it will break. So long as it is afloat, it will not break; but, if it goes ou a rock, of course it will. But thero is the fact that nothirg will permanently adhere to it. Many people imagine that things will adhero to it. So thes will; but thes will never be able to eat into the smootl surfa $z$, and, therefore, nerer be able to cling to it permanently; they would be riped of as easily as the inerustation of a bottle in a cellar, or as dust off a rindor.

The Cirsmanax: Perhaps you can tell us the result of your experiment on the "Buffalo." 
Mr. LEETCE: The result has been completely gitecessful. I cxhibit a piece of the glass sheathing that was twelre months on; there is nothing more on it now than there was at first. I should not think of putting glass on so thick as that, nor would I think of doing it in the ma it was done, for it was done in a liurry. The great object is to preserve the iron. Iron, at present, is not being treated in tho way it ought to be treated for sea-roing ressels. My orn impression is, that if the iron was left mith its own natural skin, it nould bo much better than with any of the applications that lare been put upon it up to the present time.

II. Morser: I hare listened with great pleasuro to Captain Warren's paper. With regard to one remark that lic made upon the friction of water on iron my experience is rery different. I left PIgmouth Sound in 1853 on a cruise. We rent to Lisbon and JIadeira, and different places; but before we left, being an engineer on board the ship, $I$ put a piece of tallow on the driving side of the serem. We came back from Lisbon, after stcaming some thousands of miles. We then steamed up the Baltic. By-and-bje me lifted our screw for examination, aud, to my astouishment, this piece of tallow was still on the driving side of the screw. There was a remark made by Captain Warren which, as Mr. Peacock is not present, I wish to colrect. IIo said that Peacock's composition contained copper.

Captain Wannex : I beg your pardon.

Mr. M Iorsex: That is not the case, for it contains no copper, and is perfectly harmless. Mr. Gisborne spole about tho cost of his composition. If the "Valiant" las on one sile 8 s $\mathrm{cnt}$., how is it that the "Kingston" of 700 tons takes $10 \mathrm{cwt}$.? and to that has to be added the cost of docking and preparing the ressel. $\Lambda$ s to the "Kingston," I do not know whether MIr. Gisborne intends his composition to dry; if so, why was she kept in dock so long after it was put on? Aud this moruing, at seren o'clock, the composition was just as wet as when it was put on.

The Crtarnsus: Where is she docked?

MIr. Jorser : At Fleteher's dry dock. I should also like to hear what was the Admiralty Report of MIr. Gisbonne's composition on the trials that hare been made.

Dr. Counis Brows: Maj I make one remark with reference to the preparation of $\mathrm{Mr}$. Gisborne? It is stated that it consists of mercury, and other combinations, xith lead and oily substances; that the destruction of the animaleule and marine uiga, takes placo from galrauic action. I rather attribute that to other changes. Hle has forgotten that where oil comes in contact with the galvanic current, the galranic action ceascs. There is nothing so destructire of galranic action as oil. One proof I will gire you is the steamboiler, where an electric current is giren off a stcam-boiler it is corrected by a few drops of oil. The anti-fouling poisons that result from the use of mercury, I should rather attribute to the calomel that is formed. The fatty substance that is produced destroys galranic action.

Captain SELTrS, R.N.: I wisl to dram Captain Warren's attention first to a point which I do not think he brought out with sulficient importance-that of the rirets passing through the felt, in some instances, and touching the iron underneath. That rould be sure to produce an aceumulation of electrie action, duc to the tro metals coming in contact at those points. There rould be a strong local action set up. Secondly, to the fact, that whererer you put copper and iron together in a ressel, exposecl not alone to the water of the sea, but eren to the moisturo of the atmosphere, there you will ineritably hare a strong galvanie action. There is no known means of stopping that. Probably, if you could keep a band of grease at the junction, that rould be more efficient thin mood or angthing clse. There is no part at which there is not a deposit of salt water upon it, and that salt water is the conductor to continue Galrauic action through. I think it would be chenper to build our ships of copper than to go into plans for mahing copper bottoms to iron slips. If we are in that way to accomplish the object in riew, it clearly nust be by abandoning iron battoms of ships altogether, and haring the whole outside of the ship of rood. If you can do that, and haring done that, if you can keep the ship from straining, opening her bow ends, and letting in the water to the inside iron, then you might succed; but short of that, I am sure the galranic action will go on. With regsed to the black fluid of which Captain Warren spoke, as oozing from behind the plates of the "Rojal Oak," it is nothing but the gallic acid acting upon the iron, and producing 
tanno-gallate of rron as a result of an electric current betreen tho coppar and the iron, the iron forming the more destructible metal in the couple. We hare there, in the iron, the oak, the gallic acid, an action going on which has this result, that the iron becomes the positive metal; the copper is protected from that oxidation which is the only means of prerenting the deposit of all substances on the bottom of a slip. So sure as jou prerent exfoliation, whether that exfoliation is produced by the destruction of the copper, or the destruction of any other substance that you choose to put there, so sure are you to hare a deposition of barnacles, grass, sea-meed, and other materials. Ifere is a bottle which the Secretary has been hind enough to bring for your inspection. I was arrare that in the MIuscum and clscwhere there rere a great number of bottles that had been recorered from the sca at rarious times, and which lare been corered with barnacles. Sir Edmard Belcher has secn not only submerged bottles, but bottles which floated about the ocean perfectly corered with barnacles and sea-weeds. I may mention a curious fact to shom the mas in which Naturo obriates this deposition of animalcula when one of her operations is stopped. In the North Pacific we camo across a large old whale, which had becomo discased, and which was so corered with barmacles and slell-fish from head to tail, that we really took it for a half-tido rock, and we lowered our boats to examine it. The only way we could account for it was, that the fish was diseased, and that it had ceased to secrete the mucus which all fish secrcto. in health, and which protects them from the deposition of barnacles.

Sir EDTARD BEICHER: All mhales hare barnacles.

Captain SeLrTx: There is the barnacle proper to the rhale, just as there is the louse proper to the salmon, but that is not the kind of barnacle that we saw. The practice of coppering ressels is now going out. As regards the nooden and copper ressels of which Sir Edward Belcher spoke, there is no possible doubt that if Jou sacrifice anj one metal in a couple, you may protect the other. I had a wooden ressel on the coast of Africa, whose iron rudder was in a state like red cheese, from galranic action; and as for stopping that by the application of felt, There Jou hare copper nails passing through it and the points touching the iron, jou could not do it. IIr. Gisborno has brought before us a composition in which mereury plays a part. I nm sure he is too good an clectrician not to sce that there are no two metals in contact in salt water, in which a galranic action does not go on. I attribute the success of his composition moro to the fact that his paint is so madlo that it gradually rears off, than to the fact of its haring any mereury at all in the composition. I think the probability is that with copper jou get a more energetic action, but with mercury, you will get some, in any of its forms. The object of all compositions, hitherto, has been to protect ships' bottoms, not alone from oxidation, not alono from fouling, but to do both at the same timo; and I do not think, unless we get somo npplieation of the mineral oils that hare been spoken of in this theatre, that re shall be suecessful. The plan of allowing the oil to low out of the ship's bottom lias this to recommend it- that whererer grease or oil from a ship's bottom is allowed to come out from the bilge pumps, there you find, in the immediate vicinity, and in a line upwards to the surface of the water, an entire freedom of attachment of any description. Somo will say it is due to the frictional action of the water. I confess I think it is more due to the oil that is oozing out, being carried against the ship's botton, and greasing the surface in its passagc upwards. I see no possible reason why, if the oil be emitted at the bottom of the ship, you should not produce that action orer the whole surface, that jou hare produced orer a small portion of the surface. I take the greatest interest in the subject, and $I$ hare my best thanks to gire to Captain Warren and Mr. Gisborne for bringing forward the subject, for as I said in a former paper, the whole secret of suecess in naral warfare must depend upon sFeed and the power of keeping up that speed for the greatest amount of time.

Mr. IEETCI : Speaking of oils, you all know that fatty matter mill craporate after a certain time and will become dry. With regard to glass, if a bottle is sunk to a number of fathoms in the sea, and is allowed to remain there, things mill accumulate upon it; but mhere a ressel is kept moring about in the sea, there is rery little chance of anything adhering to it. But barwacles will not adhere permanently to glass placed on ships' bottoms. The only instance I know of is that in the case of a 
bottle obtained from the wreck of the "Rojal George;" there, one incrustation had actually eaten into the glass, it haring been sunk nearly a lundred years.

Captain W FARREx: I am very sorry that MIr. Hay should hare been so distressed. I really thought, in what he said on the occasion in question, that it was a little piece of sareasm on lis part, and you see it by the context:-" I think the subject should be taken up by chemists who should rork at it for trrenty or fire and twenty scars."

Mr. IIAF: "Who hare worked at it for twenty or fire and trenty Jears?"

Captain Wanres: I quote from the rolume of the Transactions of Naval Architects referred to by me. Mrr. Hay is made to say, "I think the subject should be taken up by chemists who should work at it for trenty or firo and trrenty jears," and as the context shows, Mrr. Has could get no reply to his scientific questions I do not think he gave limself a rery long period to settle the question. MIr. IIay, as the Admiralty chemist, tells us that wood is a rery perfect conductor between two metals, Mr. Reed, the Chicf Constructor, sass that it is the only effectual interposition, so thinks diferently, but I do not seo how that can affect Mr. Iras in any way as a scientific chemist, which Mr. Recd certainly is not. As far as the "Recruit". is concerned, I quoted the "Recruit" as I quoted other ressels; I quoted the case of the "Megxra," which was a much worso caso than that of the "Recruit," and in which Mr. MIcInnes and Mr. Mray's compositions were used on different sides, and she was described as a putrid mussel-bed. There was one portion which I had noted, but which appeared to me so strongly worded, that $I$ did not intend to read it. I will read it now, it is from the naral intelligence of the "Times":-

"The 'Tarrior,' 40, iron frigate, Captain Arthur A. Cochrane, C.B., in the dock at Portsmouth, has, according to established custom, had her hull, below the mater-line, and the compositions and experimental sheathings with which it is coated, examined and reported upon to the Admiralty by the officials of the dockyard. It is four and a half months since the "Warrior" was in dock. She was then coated below the water.line with the preserratire and anti-fouling composi. tions prepared by the Admiralty's Chemical $\Delta$ ssistant, and at the same time had three patches of 'Brown's vitreous sheathing ' at tached to her port side. The ship's bottom, as she now lies in dock, has the appearance of a Tell-made thrummed-mat, being corered with a fine crop of tuft weed, which must hare grown at the rate of abont three-quarters of an inch per month since the slip has been afloat, to reach its present condition. The vitreous sheathing had less of this weed upon it than the compositions, and they haro adhered to the ship's bottom with two exceptions."

AIr. Har: Mray I be allowed to make one obserration upon that? With respect to that last quotation which Captain Warren has been so polite as to introduce, that las been publicly denied in the nerspaper; and I assuro jou that Captain Warren, who is in the habit of secing ships, might hare brought forward some that had come under his notice personally, rather than hare taken up loose newspaper reports. There is one ressel that has been serenteen months coated since last doched-she lias been coated for sorenteen years on wy plan and the iron and rirets are as good as when put together. Captain Warren knows this, as at the time of the examination of the mortar-float, sheathed on his plan, she ras in the same dock.

The Cranrax: The simple fact is, Captain Warren has read an extract from a nerspaper, and you state that it is not correct.

AIr. III : Certainly so. I wished to make a fer obserrations upon the subject, to confute the arguments that hare been brought forward, followed by these bestiful illustrations.

Sir IDWARD BeLCren: If the accounts that re read in the newspapers were to be taken as facts, the Admiralty would be rery much to blame for employing Ir. Iray any longer. But, if the Admiralty are satisfied, I think re ought to be.

IIr. GIsmorse: In reply to the remarks upon my paper I will not detain you more than one or two minutes. 1st. In reply to IIr. Iralkett, wo tried corrosire sublimate and other preparations of mercurs, and found them to be exceedingly deleterious to the efficacy of the paint. 2ndly. Dr. Brown remarked that there could be no electric action upon mollusks that attached themselres to the paint on 
account of the oil in it. But, when paint is completely filled with minute particles of quicksilver, so soon as a mollusk fastens upon it the fish feeds upon the skin of oil until, by uncorering a globulc of mercury, galranic action acts upon it. Captain Selwyn mentioned that no metals como in contact with salt water without galranic action arising; the merciry $I$ use mould not howerer athere to iron but for the oil which insulates it from the iron, as already cxplained in my remarks upon adhesion. One of the patentes I hare named, cmploys mereury with grease to prerent galranic action upon one side of the zines in a batters. Fou have heard that red lead is a rery good anti-corrosire; yet, when brought into competition with my paint, as ou the plate nor before jou, you nill notice that tro coatings of the best red lead have not prerented destructive corrosion, while my side is perfectly clean and free from all corrosion, and what is remarkable, as you will perceire upon closer inspection, is that eren the hammer marks made in flattening the plate and which scaled the iron show through the paint without any corrosion upon their abraded edges. This plate has been submerged sis months and is authenticated by Idord's agent at Milford Maren. In reply to Mrr. MIosses I beg to state that wo clid not paint the "Resistance," the "Taliant" being the only ono of Iler IIajesty's ships under experiment. She went into dock on the 12th, and had three contings, cach coating drying within trenty-four hours, and in reference to the merchantman, "Iringston," I ascertained upon my return to town, after a fort. night's absence, that good boited linseed oil had not becn used with my paint, and the paint will not dry quickly unless such oil is used. If jou paint two plates of iron with my paint and allow it to set an hour or two and then submerge one plate, the plate so stbmerged will dry more quickly than the one left in the air. The best proof, howerer, of all paints is to test them by actual experiment at sea.

Captain WinRex: Captain Selwyn made a remark as to tho rirets. The felt which was tried before mas a rery thin felt. The felt nor is so thick that if the rirets were driren in in the form of nails, they would not penetrate through it to the iron. Mrr. Beale asked a question as to the length of a ship's commission. 1 commission is usually for threc jears, so we beliere this copper will last sir years. I now think that $I$ hare answered all the questions put to me. I knew rery well before I camo here that composition-makers and African trarellers aro tho most belligerent of people.

The CnsIrusax : I will not detain jou long by making any obscrrations myself. I think the conclusions to which we must all come are :-first, that it is a subject of the rers greatest importance; secondly, that it is not at all an casy problem to solre how to cont the bottoms of iron ships. I think the faet of the rery large number of patents, and the inuumerable substances which hare becn tricd on ravious occesions, are sufficicut proofs that the subject is not casily handled. I belicre I mas say that we lave not, as jet, hit upon the right method of preserring iron ships' bottoms. I think it is a matter of regret that Captain Tramen has not becu able to tell us that his sheathing has been tried at sea. It is quite possible that his plan mas bo so far good as to preserre an iron mortar-bont while in larbour; but so far as I understand him, it has not been tried at sca.

Captain Warrex: It has not.

The Cusmess : Therefore, $I$ quite agree with what Mr. Gisborno sail just now, that the only way to prore these compositions is to try them at sea. I hare a recollection of haring oecasionally been taken to a ship in dock, and $I$ hare been told to look at one side and then at the other; and I could really sec rery little diference. On one side was MIr. Hay's composition, and on the other was what we ealled the Woolwich composition, which is simply coal-tar and a little spirits; and I could sce no difference. With respect to the new patent which Sir Edward Belcher mentioned for preserring the stone-work of the Houses of Parliament, so far as I hate heard, it is a vitreous composition.

Sir EDTrard Bexcner : No. I cannot inform jou of the secret.

The Cmamuar: $M_{y}$ impression was, that being a ritreons composition, all the objections Thich Sir Echrard Beleher applied to Jir. Icetch's plating of glass rould apply to this ritreous composition. Hlorerer, I shall not detain the meeting by going into a rariety of points, cspecially witl refcrence to the coppering of iron-cased 
ships. The matter has been rers much considered, and I do not know how the question stands at present. I thin the "Royal Sorereign" was corcred with peculiar corrugated plates.

$\Lambda$ AIEsBen: Thes hare been remored.

The Crumsins : I do not know the present state of the "Caledonia." A belt of wood was originally placed between the AIuntz's metal on her bottom and her iron plates; it was mell-knomn that damp wood is a partial conductor, still it was supposed that this would be a better plan than bringing the BIuntz's metal right under, and in contact with, the armour-plates. If that liad been done, there is no donbt that the armour-plates would hare been ruined. I liare now only to thank Captain Warren and MIs. Ctisborne for preparing these papers and bringing them before us. 